\title{
Implementation of Outcome-Based Education in Universiti Putra Malaysia: A Focus on Students' Learning Outcomes
}

\author{
Mohd Ghazali Mohayidin \\ Faculty of Agriculture, Universiti Putra Malaysia \\ 43300, UPM Serdang, Selangor, Malaysia \\ Tel: 60-3-8946-4120Ｅ-mail: mghazalee@putra.upm.edu.my \\ Turiman Suandi, Ghazali Mustapha \& Mohd. Majid Konting \\ Faculty of Educational Studies, Universiti Putra Malaysia \\ 43300, UPM Serdang, Selangor, Malaysia \\ Tel: 603-8946-8247, 603-8946-8180, 603-8946-6136 \\ E-mail: tj@putra.upm.edu.my,gm@educ.upm.edu.my, majid@educ.upm.edu.my \\ Norfaryanti Kamaruddin, Nor Azirawani Man, Azura Adam \& Siti Norziah Abdullah \\ Centre for Academic Development, Universiti Putra Malaysia \\ 43300, UPM Serdang, Selangor, Malaysia \\ Tel: 60-3-8946-6175 \\ E-mail: norfaryanti@putra.upm.edu.my, norazirawani@putra.upm.edu.my
}

\begin{abstract}
The move towards applying outcome-based education in teaching and learning at tertiary education level has become an important topic in Malaysia. Apart from the three learning domains; namely, cognitive, psychomotor and affective, the Ministry of Higher Education has determined eight learning outcomes which are important in providing wholesome quality education to students. Universiti Putra Malaysia has conducted a study to determine the extent to which these learning outcomes have been achieved. The result shows the overall perceived achievements were as follows: cognitive domain was at level four, psychomotor domain at level four and affective domain at level three. The Ministry's set of learning outcomes revealed the following results: The highest score went to providing KNOWLEDGE to students, while the least achievable learning outcome was MANAGERIAL AND ENTREPRENEURIAL SKILLS. The results infer that soft-skills among students were lacking and this problem needs to be addressed quickly and effectively.
\end{abstract}

Keywords: Outcome-based education, Learning domains, Learning outcomes, Cognitive, Psychomotor, Affective

\section{Introduction}

The move towards applying outcome-based education (OBE) in handling teaching and learning instructions at tertiary education has been one of the most widely considered topics in educational sector in recent years. Concerns on the fact that the education system widely practiced ill-adequately prepares graduates to face challenges in life and at work places in the 21 st Century have prompted people across the world to explore new ways of designing and re-branding academic and educational curriculum.

OBE was developed and has been in practiced since 1950s in Malaysia. It is now being implemented at all levels of education especially at higher institutions of learning. OBE is an education philosophy organized according to several basic beliefs and principles for the learners to practice in order to become successful in life when they finish their studies. It starts with the belief that students can benefit from any educational program only when the instructional outcomes can be measured as a result of any instructions. Higher educational institutions should be able to monitor the levels of outcomes expected from any academic courses through the propagation of quality teaching by qualified lecturers. These will in-turn result in meaningful learning experiences for the students. Instructions should be strategized in accordance with the desired exit outcomes. This would be largely dependent on relevant instructional 
strategies utilized by the lecturers in order to achieve relevant skills with high standards of achievement in line with high expectations of all students.

Universiti Putra Malaysia (UPM) has implemented OBE in its teaching and learning strategy. Apart from the three learning domains; namely, cognitive, psychomotor and affective, UPM has also emphasized that students achieve eight learning outcomes as determined by the Ministry of Higher Education (MoHE) which are important in providing wholesome quality education to students. The learning outcomes are Life Long Learning and Information Management, Communication Skills, Managerial and Entrepreneurial Skills, Psychomotor / Practical / Technical Skills, Knowledge, Social skills and Responsibility and Professionalism, Values, Attitudes and Ethics. This study was conducted to determine the extent to which the learning outcomes have been achieved.

\section{Outcome-based Education at Universiti Putra Malaysia (UPM)}

At its most basic level, OBE is where the school and community first determine what skills and knowledge students should possess upon graduation, then work backwards from there to develop curriculum, strategies and materials to help students achieve those goals, or "exit outcomes". Generally, in OBE learning, all educational programs and instructional efforts are designed to have produced specific, lasting results in students by the time they leave school (Blust 1995). Schools that have successfully implemented OBE programs which ascribed auspicious results such as Alhambra High School in Phoenix, Arizona, reported significant improvements in attitude and performance by both students and teachers within the first year (Briggs 1988). And, after four years of OBE, the Sparta School District in Illinois achieved radical gains in grades and test scores in spite of its previous financial and labour problems (Brown 1988).

In Universiti Putra Malaysia (UPM), the teaching and learning instructions are conducted using the semester system where one academic year is divided into two semesters. During the course of each semester students will be given instructions according to the aims and objectives of each subject/course offered by the university. Evaluations on students' academic performance are conducted in the forms of quizzes, assignments, examinations and other forms of assessment such as practical works and field practices.

There are 64 academic programs offered by 16 academic faculties in UPM. Each program needs to fulfil a total number of credit hours for a student to undertake before he or she is considered qualified for a degree in that program. Some of the programs prescribed major and minor courses in related fields as a requisite to qualify for a degree. The academic courses offered by each faculty can be divided into three different categories; the university courses, core courses and elective courses. The core courses are compulsory for all students to take, lest, their study will be considered incomplete. While the university and elective courses are courses offered for the purpose of enriching students' general knowledge in fields related to their programs. Students have the freedom to choose from the list of courses provided by the university.

UPM has a vision to become an internationally renowned university. Though the University has achieved much and made great strides in recent years, particularly in the areas of research and innovation, there is still much to be desired and done before UPM can attain the status of a first-class, world-renowned institution of higher learning. If UPM is to achieve its goal of becoming an overall excellent institution, it must address the claims made by some quarters that the University is not actually producing world-class, 'top quality' graduates that are highly sought after by prospective employers. For example, there are anecdotal evidences that come from government officials, the media as well as industry representatives in Malaysia which indicate that many UPM graduates are found to be having difficulty and weak in the skills of communication and creative self-expression to such an extent that they even have difficulty in getting through their job interviews. Once hired, many are said to be lacking in higher-order and lateral thinking skills, creativity, analytical skills and other skills required to make them efficient and proficient problem solvers and decision makers.

In order to produce quality graduates at UPM, teaching and learning instruction, assessment procedures and techniques should be highly tailored for the desired exit outcomes (Universiti Putra Malaysia 2004). UPM's goal of producing first-class graduates should be reflective in the teaching and learning objectives which are observable and achievable via the adequate and appropriate teaching and learning approaches and strategies. Assessment should possess high degree of discriminating effect that classifies student according to their actual skills and abilities. There is a wealth of assessment methods used in higher education to assess students' achievements. The choice of assessment procedure should be tailored to meet the learning needs of students.

The intended goal also implies that UPM lecturers should be equipped with first-class quality of teaching instruction and are capable of delivering the finest education to their students. Lackadaisical instructional strategies with lacklustre attitude would not be at all warranted. There is a need to be flexible in approaching and creative in strategising while meeting the needs of both students and lecturers in the process of achieving the course learning objectives. Lecturers can choose suitable learning methods such as Problem-Based Learning (PBL), Student-Centred Learning (SCL) and other relevant approaches. There is also a need for lecturers to undergo courses in aptitude assessment to determine their 
teaching styles and preferences, including obtaining personality and socio-historical profiles that underlie their educational beliefs and practices. This type of assessment can provide much toward determining the training needs of lecturers that will ensure the right ingredients that are necessary to make the needs of students.

The purpose of OBE is to equip all students with the knowledge and competencies needed for their future success. Thereby, it is necessary to implement programs and conditions that maximize learning experiences. The objective of the study is to assess lecturer's perception on how far the students have achieved the stated learning domains and learning outcomes.

\section{Literature Review}

Learning outcomes can serve as a benchmark to measure a success of a university. Learning outcomes as 'being something that student can do now that they could not do previously' are changes in people as a result of a learning experience (Watson 2002). Learning outcomes can be used in a way that meets the needs of all stakeholders in university (i.e. the student, the lecturer and external parties). It has been theorized that learning outcomes consists of three broad categories or domains of learning as shown in Table 1.

"Student learning outcomes," on the other hand, encompass a wide range of student attributes and abilities, both cognitive and affective, which are a measure of how their college experiences have supported their development as individuals (Bloom 1977). Cognitive outcomes include demonstrable acquisition of specific knowledge and skills. Affective outcomes are also of considerable interest; how has their college experience impacted students' values, goals, attitudes, self-concepts, worldviews, and behaviours? Psychomotor domains involve physical movement, coordination, and use of the motor-skills areas. Development of these skills requires practice and is measured in terms of speed, precision, distance, procedures or techniques.

The outcomes also serve the following purposes:

- The specific outcomes of the learning areas are organized so that UPM can prepare learning programmes appropriate for each phase of education.

- Lecturers will prepare lessons and activities to assist student in meeting the required outcomes.

- The student will be assessed to see if he or she can demonstrate the outcomes. The results of the assessment show whether the student is competent or still needs assistance in order to achieve a particular outcome.

- If a student still needs assistance, more activities are designed around the same outcomes in the learning programme. These activities address the learner's weaknesses.

- If the student is competent, he or she can start working on more complex outcomes

The purpose of student learning outcomes is to ensure that the graduates acquire the essential core of a university-educated person in keeping with the university's mission and its strategic plan. In addition, the learning outcomes provide an opportunity for graduates to acquire the knowledge and skills. The MoHE has determined and categorized the learning outcomes for the local institutions of higher learning as shown in Figure 1.

Teaching approach can be defined as the behaviours or actions that lecturers and learners exhibit in the learning exchange (Heimlich and Norland 2002). Teaching behaviours reflect the teachers' beliefs and value about the learner's role in the exchange. Learners' behaviours provide insight into the ways learners perceive, interact with, and respond to the environment in which learning occurs.

Each teacher is unique and can use his or her style to be as effective an educator as possible. In the teaching and learning contexts, teaching effectively is a learned skill requiring knowledge of educational process, mastery of the instructional methods, and an ability to use with a variety of learners and setting (Ladd and Ruby 1999).

\section{Methodology}

This study involves lecturers teaching diploma and degree programs in UPM. The instrument was developed by a research team. The instrument has been developed by focusing on two (2) major domains, they are; teaching and learning taxonomy (cognitive, psychomotor, and affective) and MoHE learning outcomes. Levels and explanation for each domain are referred from Bloom's Taxonomy.

The instrument also measures the perceived attainment level of learning outcomes that have been developed by MoHE for courses that have been taught in the semester. The scale is from 1 to 10 where 1 indicates the lowest perceived attainment level of learning outcomes and 10 indicates the highest perceived attainment level.

By the same token, the instrument covers respondents' profile and the background for courses taught. The respondents are UPM lecturers from all faculties. The instrument was distributed to the departments in faculties according to the number of degree courses taught at week 10th. The instrument was distributed to all lecturers from each faculty via the Head of Department who will in-turn sent the completed ones back to CADe. 
The entire courses offered from 16 faculties are categorized into three clusters which are Social Sciences, Biosciences \& Medical and Physical Sciences \& Engineering. Courses offered by Faculty of Educational Studies, Faculty of Human Ecology, Faculty of Economics and Management and Faculty of Modern Languages and Communication are categorized under Social Sciences cluster while Faculty of Agriculture, Faculty of Forestry, Faculty of Veterinary Medicine, Faculty of Food Science and Technology, Faculty of Medicine and Health Sciences are categorized under the cluster of Biosciences and Medical. Faculty of Engineering, Faculty of Science, Faculty of Design and Architecture, Faculty of Computer Science and Information Technology and Faculty of Environmental Studies are chosen to represent the cluster of Physical Sciences and Engineering. Table 2 shows the responses from each cluster.

The data was analyzed using descriptive analysis to determine the frequency, mean and standard deviation. Analysis of variance, using ANOVA, was to see whether there are significance differences between teaching and learning domains and learning outcomes among clusters of Social Sciences, Biosciences \& Medical and Physical Sciences \& Engineering.

\section{Results and Discussion}

\subsection{Students' Attainment based on Learning Domains}

\subsubsection{Cognitive}

The cognitive domains involve knowledge and the development of intellectual skills. These domains consist of six major categories starting from the simplest behaviour to the most complex. The categories can be thought of as degrees of difficulties. Table 3 shows the distributions of response.

\subsubsection{Psychomotor}

The psychomotor domain consists of physical movement, coordination, and use of the motor-skill areas. Development of these skills requires practice and is measured in terms of speed, precision, distance, procedures, or techniques. Table 4 demonstrates the distributions of response.

\subsubsection{Affective}

This domain includes the manner in which the study deals with things emotionally, such as feelings, values, appreciation, enthusiasms, motivations, and attitudes. The other skills in the affective domains were fairly utilized by the lecturers as illustrated in Table 5.

The result shows that from general perspective, the level of perception perceived by all lecturers in the domains used in their teaching instruction in Semester I 2006/2007 and Semester II 2006/2007 were consistent as shown in Table 6.

\subsubsection{Analysis of Variance for Teaching and Learning Domains}

Table 7 shows the relationship between level of perception of utilization of teaching and learning domains by lecturers from different clusters.

\subsection{Learning Outcomes}

Table 8 presents the distributions of response by the perceived attainment level of learning outcomes. The details of the percentage levels of attainment of learning outcomes for all courses using eight elements of learning outcomes by clusters are shown in Appendix 2.

Using the Likert scale ranging from 1 to 10, where 1-3 indicates 'Low', 4-6 indicates 'Moderate' and 7-10 indicates 'High', it is noticed that the overall perception ranged from low to high, the MANAGERIAL AND ENTREPRENEURIAL SKILL were regarded as 'Low' in terms of attainment, while the rest lies in the region from 'Moderate' to 'High'. The results were illustrated in Table 9. The details of the means levels of attainment of learning outcomes for all courses using eight elements of learning outcomes by clusters are shown in Appendix 3.

\subsubsection{Analysis of Variance for Learning Outcomes}

Illustrated in Table 10 were the results for relationships of the attainment of learning outcomes by lecturers from different clusters

\section{Summary and Conclusion}

This paper has indicated that majority of the lecturers of UPM were able to infuse the required levels of cognitive, affective and psychomotor domains in their instructions in line with the effort of producing students with wholesome and global qualities. The utilization of all levels of domains from the three major constructs was prevalent. As indicated by the instructions conducted in both semesters 1 and 2, all domains of cognitive, psychomotor and affective were evenly utilised across the board.

The infusion of low order cognitive domains in an instruction, which concentrates on providing students with basic understanding of facts is equally as important as providing them with the higher order categories that call for the 
employment of critical and creative thinking skills. Students need to understand the facts of the matter before engaging in employing those facts for higher order thinking, such as to analyse, synthesise, evaluate, or even spiritualize. There is a need to highlight that each instruction must ensure that higher order thinking skills must be made the ultimate aim. Some lecturers were engaging on the low-order cognitive domains in their instructions could be due to the fact that students were newly recruited and there is a need for them to understand the basics of instruction or it could also be due to the objective nature of certain subjects which require employment of literal instruction. This needs to be ascertained.

The utilisation of psychomotor domains was well spread out in the instructions. As indicated by table 4, students were able to utilise levels 3 and 4, i.e. 'guided response' and 'mechanism'. This shows that some students still require instructors' guidance in their psychomotor activities. Nevertheless, it is acknowledge that the other half of the majority is already gaining confidence in doing things on their own. Overall, about $26 \%$ of them can be considered substantial in attaining the ability to engage the higher order categories of the psychomotor domains i.e. 'complex overt response', 'adaptation', and 'origination'. It is acknowledged that a sizeable percentage of the students were already attaining the higher order psychomotor skills.

The affective domains were well infused in the instructions. Students were seen to be well equipped with all the domains that are important to their development of moral, attitudes, and feelings. This aspect of development is of utmost important to ensure that intellectual development as prescribed by the cognitive domains is fairly substantiated by the moral aspects of character development. This is in line with the intention of producing students who are not only cognitively smart but also morally upright and upstanding.

In the effort of producing first class graduates with wholesome quality, characteristics and aptitudes in UPM, we need to also consider assessment procedure and approaches that are truly valid and reliable to measure the learning outcomes of the students. The goal of the producing first class student must be commensurated by first class teaching instructions. The assessment procedure used to assess students' performance must possess high degree of discriminating effect so that students' categorization in term of their academic performance is highly reliable.

\section{References}

Blust, Adam. (1995). The Debate Over Outcome Based Education, News \& Views, March 1995.

Briggs, David A. (1988). Alhambra High: A 'High Success' School. Pg. 46, 2: 10-11.

Brown, Alan S. (1988). Outcome-Based Education: A Success Story. Pg. 46, 2: 12.

Watson, P. (2002). The Role and Integration of Learning Outcomes into the Educational Process. Active Learning in Higher Education 3(3), 205-219.

Bloom, B.S. (1977). Taxonomy of Educational Objectives: The Classification of Educational Goals. Handbook I: Cognitive Domain. New York: Longman.

Universiti Putra Malaysia. (2004). Module 1 Learning Outcomes Initiative, How to develop Outcome-Based Programme. Centre for Academic Development (CADe), UPM.

Heimlich, J. E. \& Norland, E. (2002). Teaching Style: Where Are We Now?. New Directions for Adult and Continuing Education. No. 93: 17-25.

Ladd, P. \& Ruby Jr., R. (1999). Learning Style and Adjustment Issues of International Students. Journal of Education for Business 74, no. 6: 363-367.

\section{Appendix}

Appendix 1: Ministry of Higher Learning's Learning Outcomes

i. Knowledge

- Demonstrate possession of a body of knowledge of the relevant discipline.

- Ability to apply the knowledge.

- Apply principles to new situation.

ii. Professionalism, Values, Attitudes, Ethics

- Possess technical knowledge and skills with commitment to a set of shared values.

- Have autonomy to enforce the values.

- Have responsibility to promote, protect and enhance the values for the benefit of the consumers, the profession, self and society at large.

iii. Social skills and responsibility

- Able to participate in appropriate community actions in collaborative multidisciplinary and multi sectoral teams 
- Demonstrate understanding and sensitivity to as well as respect of cultural diversity and beliefs.

iv. Psychomotor, practical and technical skills

- Possess knowledge, skills and attitudes for the effective and efficient execution of psychomotor, practical and technical skills.

v. Communication skills

- Able to create an environment of sensitivity to cultural and personal factors for effective communication and improved interactions with and among:

○ Peers

○ Supervisors

○ Members of work team

- Colleagues

- Public

vi. Life long learning and information management

- Able to use ICT to assist in work processes.

- Able to anticipate and show willingness to participate in charge by reflecting on own limitations and self assess, accepting peer evaluation and undertaking continuous self-directed study.

vii. Critical thinking and scientific approach

- Able to apply problem-solving process in learning.

- Synthesize data from different sources and apply probability theory and evidence to refine hypotheses.

viii. Managerial and entrepreneurial skills

- Ability to apply the principles of management in business activities.

- Able to access and use information from various sources for problem solving and decision-making. 
Appendix 2: Percentage Perception Level of Attainment of Learning Outcomes through Courses

\begin{tabular}{|c|c|c|c|c|c|c|c|}
\hline \multirow[t]{2}{*}{ Learning Outcomes } & \multirow[t]{2}{*}{ Cluster } & \multicolumn{3}{|c|}{ Semester I 2006/2007 } & \multicolumn{3}{|c|}{ Semester II 2006/2007 } \\
\hline & & 1 & 2 & 3 & 1 & 2 & 3 \\
\hline \multirow{3}{*}{$\begin{array}{l}\text { Life } \text { Long } \text { Learning } \\
\text { and } \\
\text { Management }\end{array}$} & Social Science & 2.7 & 24.6 & 72.8 & 3.7 & 13.0 & 83.3 \\
\hline & $\begin{array}{l}\text { Biosciences } \quad \& \\
\text { Medical }\end{array}$ & 10.2 & 24.4 & 65.5 & 10.2 & 15.7 & 74.1 \\
\hline & $\begin{array}{l}\text { Physical Sciences \& } \\
\text { Engineering }\end{array}$ & 8.9 & 26.2 & 64.9 & 7.5 & 21.5 & 71.0 \\
\hline \multirow{3}{*}{$\begin{array}{l}\text { Communication } \\
\text { Skills }\end{array}$} & Social Science & 4.7 & 23.6 & 71.8 & 4.7 & 15.3 & 80.0 \\
\hline & $\begin{array}{l}\text { Biosciences } \quad \& \\
\text { Medical }\end{array}$ & 12.2 & 32.0 & 55.8 & 14.2 & 28.4 & 57.4 \\
\hline & $\begin{array}{l}\text { Physical Sciences \& } \\
\text { Engineering }\end{array}$ & 8.4 & 8.4 & 54.0 & 15.1 & 32.8 & 52.2 \\
\hline \multirow{3}{*}{$\begin{array}{l}\text { Critical Thinking and } \\
\text { Scientific Approach }\end{array}$} & Social Science & 3.7 & 30.6 & 65.8 & 5.1 & 26.5 & 68.4 \\
\hline & $\begin{array}{l}\text { Biosciences } \quad \& \\
\text { Medical }\end{array}$ & 8.1 & 26.9 & 65.0 & 7.1 & 22.3 & 70.6 \\
\hline & $\begin{array}{l}\text { Physical Sciences \& } \\
\text { Engineering }\end{array}$ & 6.4 & 27.2 & 66.3 & 9.1 & 17.2 & 73.7 \\
\hline \multirow{3}{*}{$\begin{array}{l}\text { Managerial and } \\
\text { Entrepreneurial Skills }\end{array}$} & Social Science & 19.6 & 41.2 & 39.2 & 20.0 & 34.4 & 45.6 \\
\hline & $\begin{array}{ll}\text { Biosciences } & \& \\
\text { Medical } & \end{array}$ & 32.0 & 29.9 & 38.1 & 35.5 & 32.5 & 32.0 \\
\hline & $\begin{array}{l}\text { Physical Sciences \& } \\
\text { Engineering }\end{array}$ & 35.6 & 35.1 & 29.2 & 31.7 & 40.9 & 27.4 \\
\hline \multirow{3}{*}{$\begin{array}{l}\text { Psychomotor } \\
\text { Practical / Technical } \\
\text { Skills }\end{array}$} & Social Science & 15.6 & 32.2 & 52.2 & 18.1 & 31.6 & 50.2 \\
\hline & $\begin{array}{l}\text { Biosciences } \quad \& \\
\text { Medical }\end{array}$ & 14.2 & 19.3 & 66.5 & 12.7 & 21.8 & 65.5 \\
\hline & $\begin{array}{l}\text { Physical Sciences \& } \\
\text { Engineering }\end{array}$ & 10.9 & 29.7 & 59.4 & 14.0 & 21.0 & 65.1 \\
\hline \multirow[t]{3}{*}{ Knowledge } & Social Science & 0.3 & 10.3 & 89.4 & 1.9 & 4.2 & 94.0 \\
\hline & $\begin{array}{l}\text { Biosciences } \quad \& \\
\text { Medical }\end{array}$ & 2.5 & 10.2 & 87.3 & 2.0 & 6.1 & 91.9 \\
\hline & $\begin{array}{l}\text { Physical Sciences \& } \\
\text { Engineering }\end{array}$ & 1.0 & 16.8 & 82.2 & 7.5 & 8.1 & 84.4 \\
\hline \multirow{3}{*}{$\begin{array}{l}\text { Social skills and } \\
\text { Responsibility }\end{array}$} & Social Science & 3.0 & 21.3 & 75.7 & 4.2 & 10.2 & 85.6 \\
\hline & $\begin{array}{l}\text { Biosciences } \\
\text { Medical }\end{array}$ & 11.7 & 30.5 & 57.9 & 14.2 & 24.4 & 61.4 \\
\hline & $\begin{array}{l}\text { Physical Sciences \& } \\
\text { Engineering }\end{array}$ & 15.3 & 34.7 & 50.0 & 19.4 & 41.4 & 39.2 \\
\hline \multirow{3}{*}{$\begin{array}{l}\text { Professionalism, } \\
\text { Values, Attitudes and } \\
\text { Ethics }\end{array}$} & Social Science & 2.0 & 18.3 & 79.7 & 3.3 & 13.5 & 83.3 \\
\hline & $\begin{array}{l}\text { Biosciences } \\
\text { Medical }\end{array}$ & 14.7 & 26.4 & 58.9 & 15.2 & 21.3 & 63.5 \\
\hline & $\begin{array}{l}\text { Physical Sciences \& } \\
\text { Engineering }\end{array}$ & 14.4 & 31.7 & 54.0 & 14.0 & 38.2 & 47.8 \\
\hline \multicolumn{2}{|l|}{ Total } & 10.8 & 25.5 & 62.6 & 12.1 & 22.6 & 65.3 \\
\hline
\end{tabular}

Note: 1- Low 2-Moderate 3-High 
Appendix 3: Mean Score for the Attainment of Learning Outcomes through Courses by Clusters

\begin{tabular}{|c|c|c|c|}
\hline Learning Outcomes & Cluster & $\begin{array}{l}\text { Semester I } \\
\text { 2006/2007 } \\
\text { (Mean) }\end{array}$ & $\begin{array}{c}\text { Semester II } \\
\text { 2006/2007 } \\
\text { (Mean) }\end{array}$ \\
\hline \multirow{3}{*}{$\begin{array}{l}\text { Life Long } \quad \text { Learning } \\
\text { Information Management }\end{array}$} & Social Science & 7.43 & 7.82 \\
\hline & Biosciences \& Medical & 6.99 & 7.20 \\
\hline & $\begin{array}{lll}\text { Physical } & \text { Sciences } & \& \\
\text { Engineering } & & \end{array}$ & 6.97 & 7.28 \\
\hline \multirow[t]{3}{*}{ Communication Skills } & Social Science & 7.35 & 7.64 \\
\hline & Biosciences \& Medical & 6.47 & 6.45 \\
\hline & $\begin{array}{lll}\text { Physical } & \text { Sciences } & \& \\
\text { Engineering } & & \end{array}$ & 6.42 & 6.28 \\
\hline \multirow{3}{*}{$\begin{array}{l}\text { Critical Thinking and Scientific } \\
\text { Approach }\end{array}$} & Social Science & 7.12 & 7.18 \\
\hline & Biosciences \& Medical & 6.97 & 7.13 \\
\hline & $\begin{array}{lll}\text { Physical } & \text { Sciences } & \& \\
\text { Engineering } & & \end{array}$ & 7.06 & 7.34 \\
\hline \multirow{3}{*}{$\begin{array}{l}\text { Managerial and Entrepreneurial } \\
\text { Skills }\end{array}$} & Social Science & 5.64 & 5.83 \\
\hline & Biosciences \& Medical & 5.19 & 4.84 \\
\hline & $\begin{array}{lll}\text { Physical } & \text { Sciences } & \& \\
\text { Engineering } & & \end{array}$ & 4.64 & 4.75 \\
\hline \multirow{3}{*}{$\begin{array}{l}\text { Psychomotor / Practical / } \\
\text { Technical Skills }\end{array}$} & Social Science & 6.43 & 6.20 \\
\hline & Biosciences \& Medical & 7.04 & 6.85 \\
\hline & $\begin{array}{lll}\text { Physical } & \text { Sciences } & \& \\
\text { Engineering } & & \end{array}$ & 6.65 & 6.78 \\
\hline \multirow[t]{3}{*}{ Knowledge } & Social Science & 8.50 & 8.70 \\
\hline & Biosciences \& Medical & 8.28 & 8.51 \\
\hline & $\begin{array}{ll}\text { Physical } & \text { Sciences } \\
\text { Engineering } & \end{array}$ & 8.14 & 7.90 \\
\hline \multirow[t]{3}{*}{ Social skills and Responsibility } & Social Science & 7.63 & 8.06 \\
\hline & Biosciences \& Medical & 6.54 & 6.46 \\
\hline & $\begin{array}{ll}\text { Physical } & \text { Sciences } \\
\text { Engineering } & \end{array}$ & 6.17 & 5.59 \\
\hline \multirow{3}{*}{$\begin{array}{l}\text { Professionalism, } \\
\text { Attitudes and Ethics }\end{array}$} & Social Science & 7.79 & 7.86 \\
\hline & Biosciences \& Medical & 6.64 & 6.55 \\
\hline & $\begin{array}{ll}\text { Physical } & \text { Sciences } \\
\text { Engineering } & \end{array}$ & 6.37 & 6.32 \\
\hline
\end{tabular}


Table 1. Learning Domains

\begin{tabular}{|c|c|c|}
\hline Domain & Learning Domains & $\begin{array}{l}\text { Teaching Strategies/ Teaching } \\
\text { approach }\end{array}$ \\
\hline $\begin{array}{l}\text { Cognitive } \\
\text { ("Thinking" domain) }\end{array}$ & $\begin{array}{l}\text { Involves the acquisition of information and } \\
\text { refers to the learner's intellectual abilities, } \\
\text { mental capacities and thinking processes. }\end{array}$ & $\begin{array}{ll}\text { 1. } & \text { Lecture } \\
\text { 2. } & \text { One-to-one instruction } \\
\text { 3. } & \text { Computer-based instruction }\end{array}$ \\
\hline $\begin{array}{l}\text { Affective } \\
\text { ("Feeling" domain) }\end{array}$ & $\begin{array}{l}\text { Involves increasing internalization or } \\
\text { commitment to feelings expressed as emotions, } \\
\text { interests, attitudes, values or beliefs. }\end{array}$ & $\begin{array}{ll}\text { 1. } & \text { Case study } \\
\text { 2. } & \text { Role-playing } \\
\text { 3. } & \text { Simulation } \\
\text { 4. } & \text { Games } \\
\text { 5. } & \text { Group discussion }\end{array}$ \\
\hline $\begin{array}{l}\text { Psychomotor } \\
\text { ("Skills" domain) }\end{array}$ & $\begin{array}{l}\text { Involve acquiring motor abilities and the } \\
\text { capabilities to perform perceptual-motor tasks. }\end{array}$ & $\begin{array}{ll}\text { 1. } & \text { Demonstration } \\
2 . & \text { Practice }\end{array}$ \\
\hline
\end{tabular}

Table 1 illustrates the three domains: cognitive, affective and psychomotor domains. In the implementation, these are the strategies that have been adopted to achieve higher level of the above three domains.

Table 2. Distribution of Respondents by Cluster

\begin{tabular}{|l|l|l|l|l|}
\hline Cluster & \multicolumn{2}{l|}{$\begin{array}{l}\text { Semester I } \\
\mathbf{2 0 0 6 / 2 0 0 7}\end{array}$} & \multicolumn{2}{l|}{$\begin{array}{l}\text { Semester II } \\
\mathbf{2 0 0 6 / 2 0 0 7}\end{array}$} \\
\cline { 2 - 6 } & $\mathbf{n}$ & $\mathbf{\%}$ & $\mathbf{n}$ & $\%$ \\
\hline Social Sciences & 301 & 43.0 & 215 & 36.0 \\
\hline Biosciences \& Medical & 197 & 28.1 & 197 & 32.9 \\
\hline Physical Sciences \& Engineering & 202 & 28.9 & 186 & 31.1 \\
\hline Total & 700 & 100.0 & 598 & 100.0 \\
\hline
\end{tabular}

$\mathrm{n}=$ number of response received

The response for the study is as presented in the above table. About 700 course lecturers responded from 1678 courses offered (43.2\%) in Semester I 2006/ 2007 and 598 course lecturers responded from 1691 courses offered (33.7\%) in Semester II 2006/ 2007.

Table 3. Distribution of Respondents by the Levels of Perception in Cognitive Domains by Clusters

\begin{tabular}{|c|c|c|c|c|c|c|c|c|c|c|c|c|}
\hline \multirow[t]{3}{*}{ Cluster } & \multicolumn{6}{|c|}{ Semester I 2006/2007 } & \multicolumn{6}{|c|}{ Semester II 2006/2007 } \\
\hline & 1 & 2 & 3 & 4 & 5 & 6 & 1 & 2 & 3 & 4 & 5 & 6 \\
\hline & \multicolumn{6}{|l|}{$\%$} & \multicolumn{6}{|l|}{$\%$} \\
\hline Social Science & 2.3 & 4.3 & 17.9 & 24.6 & 19.9 & 30.9 & 2.3 & 5.1 & 22.3 & 19.5 & 20.5 & 26 \\
\hline $\begin{array}{l}\text { Biosciences \& } \\
\text { Medical }\end{array}$ & 3.0 & 15.2 & 23.4 & 19.8 & 17.8 & 20.8 & 3.6 & 8.1 & 29.4 & 25.4 & 11.2 & 21.8 \\
\hline $\begin{array}{l}\text { Physical } \\
\text { Sciences \& \& } \\
\text { Engineering }\end{array}$ & 3.0 & 7.4 & 27.7 & 33.2 & 17.8 & 10.9 & 1.1 & 4.8 & 22.0 & 36.0 & 15.1 & 18.8 \\
\hline Average & 2.8 & 9.0 & 23.0 & 25.9 & 18.5 & 20.9 & 2.3 & 6.0 & 24.6 & 27.0 & 15.6 & 22.2 \\
\hline
\end{tabular}

Key:

1- Knowledge

2- Comprehension

3- Application

4- Analysis 
5- Synthesis

6- Evaluation

Table 3 illustrates the following interpretation; (i) 25.9\% (average) of the lecturers from Semester I 2006/2007 perceived that students were able to attain level 4 of the cognitive domains (i.e. analysis) in their. (ii) $27 \%$ (average) of the lecturers from Semester II 2006/2007 perceived that students were able to attain level 4 of the cognitive domains (i.e. analysis) in their learning. (iii) All levels of cognitive domains were fairly utilized by lecturers from all clusters. It shows that fairly equal emphasis were given towards utilizing all the domains in cognitive skills.

Table 4. Distribution of Respondents by the Levels of Perception in Psychomotor Domains by Clusters

\begin{tabular}{|c|c|c|c|c|c|c|c|c|c|c|c|c|c|c|}
\hline \multirow[t]{3}{*}{ Cluster } & \multicolumn{7}{|c|}{ Semester I 2006/2007 } & \multicolumn{7}{|c|}{ Semester II 2006/2007 } \\
\hline & 1 & 2 & 3 & 4 & 5 & 6 & 7 & 1 & 2 & 3 & 4 & 5 & 6 & 7 \\
\hline & \multicolumn{7}{|l|}{$\%$} & \multicolumn{7}{|l|}{$\%$} \\
\hline $\begin{array}{l}\text { Social } \\
\text { Science }\end{array}$ & 5.3 & 14.0 & 27.9 & 15.6 & 12.6 & 15.6 & 9.0 & 8.8 & 12.1 & 23.7 & 12.6 & 13.5 & 14.0 & 7.9 \\
\hline $\begin{array}{l}\text { Biosciences } \\
\& \text { Medical }\end{array}$ & 8.6 & 8.1 & 28.4 & 25.4 & 14.2 & 9.6 & 5.6 & 4.6 & 10.2 & 24.9 & 37.1 & 7.1 & 12.2 & 0 \\
\hline $\begin{array}{l}\text { Physical } \\
\text { Sciences \& } \\
\text { Engineering }\end{array}$ & 5.9 & 9.9 & 35.6 & 28.7 & 8.4 & 10.4 & 1.0 & 2.2 & 8.6 & 26.9 & 36.0 & 10.2 & 9.7 & 3.8 \\
\hline Average & 6.6 & 10.7 & 30.6 & 23.2 & 11.7 & 11.9 & 5.2 & 5.2 & 10.3 & 25.2 & 28.6 & 10.3 & 12.0 & 3.9 \\
\hline
\end{tabular}

Key:

1- Perception

2- Set

3- Guided Response

4- Mechanism

5- Complex Overt Response

6- Adaptation

7- Origination

Table 4 illustrates that 30.6\% of the lecturers (average) Semester I 2006/2007 generally perceived that their students have achieved psychomotor domains of level 3 (Guided Response). In Semester II 2006/2007, 28.6\% of the lecturers (average) perceived that their students have achieved psychomotor domains of level 4 (Mechanism).

Table 5. Distribution of Respondents by the Levels of Perception in Affective Domains by Clusters

\begin{tabular}{|c|c|c|c|c|c|c|c|c|c|c|}
\hline \multirow[t]{3}{*}{ Cluster } & \multicolumn{5}{|c|}{ Semester I 2006/2007 } & \multicolumn{5}{|c|}{ Semester II 2006/2007 } \\
\hline & 1 & 2 & 3 & 4 & 5 & 1 & 2 & 3 & 4 & 5 \\
\hline & \multicolumn{5}{|l|}{$\%$} & \multicolumn{5}{|l|}{$\%$} \\
\hline Social Science & 2.0 & 13.6 & 28.6 & 27.2 & 28.6 & 0.5 & 13.0 & 29.3 & 23.7 & 27.9 \\
\hline $\begin{array}{l}\text { Biosciences } \quad \& \\
\text { Medical }\end{array}$ & 2.0 & 17.8 & 35.0 & 29.4 & 15.7 & 3.0 & 13.2 & 41.1 & 27.4 & 13.2 \\
\hline $\begin{array}{l}\text { Physical Sciences } \\
\text { \& Engineering }\end{array}$ & 3.5 & 16.3 & 47.5 & 24.8 & 7.9 & 3.2 & 18.8 & 39.2 & 28.0 & 8.1 \\
\hline Average & 2.5 & 15.9 & 37.0 & 27.1 & 17.4 & 2.2 & 15.0 & 36.5 & 26.4 & 16.4 \\
\hline
\end{tabular}

Key:

1- Receiving Phenomena

2- Responding to Phenomena

3- Valuing 


\section{4- $\quad$ Organizing Values}

5- $\quad$ Internalizing Values

The above table illustrates that $37 \%$ of the lecturers (average) perceived the students have attained affective domains of level 3 (Responding to Phenomena) in Semester I 2006/2007. 36.5\% of the lecturers (average) from Semester II 2006/2007 perceived their students have also attained level 3 of the affective domains.

Table 6. Levels of Perception in Teaching and Learning Domains

\begin{tabular}{|l|l|l|l|l|l|l|}
\hline \multirow{2}{*}{ Taxonomy } & \multicolumn{3}{|l|}{ Semester I 2006/2007 } & \multicolumn{2}{l|}{ Semester II 2006/2007 } \\
\cline { 2 - 7 } & Mean & Level & Taxonomy level & Mean & Level & Taxonomy level \\
\hline Cognitive & 4.16 & 4 & Analysis & 4.07 & 4 & Analysis \\
\hline Psychomotor & 3.82 & 4 & Mechanism & 3.63 & 4 & Mechanism \\
\hline Affective & 3.45 & 3 & Valuing & 3.29 & 3 & Valuing \\
\hline
\end{tabular}

Most of the lecturers perceived that the students have achieved cognitive domains of level 4 (Analysis), psychomotor domains of level 4 (Mechanism) and affective domains of level 3 (Valuing). The analysis shows that the utilization of each of the three domains was diminishing as they moved to Semester II 2006/2007.

Table 7. Analysis of Variance for different domains by cluster

\begin{tabular}{|c|c|c|c|c|c|c|c|c|c|}
\hline \multirow[t]{2}{*}{ Taxonomy } & \multirow[t]{2}{*}{ Cluster } & \multicolumn{4}{|c|}{ Semester I 2006/2007 } & \multicolumn{4}{|c|}{ Semester II 2006/2007 } \\
\hline & & Mean & SD & $\mathrm{F}$ & Sig-F & Mean & SD & $\mathrm{F}$ & Sig-F \\
\hline \multirow[t]{3}{*}{ Cognitive } & Social Sciences & 4.48 & 1.33 & \multirow[t]{3}{*}{15.27} & \multirow[t]{3}{*}{$0.00^{*}$} & 4.16 & 1.59 & \multirow[t]{3}{*}{0.97} & \multirow[t]{3}{*}{0.38} \\
\hline & $\begin{array}{l}\text { Biosciences \& } \\
\text { Medical }\end{array}$ & 3.96 & 1.46 & & & 3.96 & 1.42 & & \\
\hline & $\begin{array}{l}\text { Physical } \\
\text { Sciences \& } \\
\text { Engineering }\end{array}$ & 3.88 & 1.20 & & & 4.09 & 1.33 & & \\
\hline \multirow[t]{3}{*}{ Psychomotor } & Social Sciences & 3.99 & 1.70 & \multirow[t]{3}{*}{4.07} & \multirow[t]{3}{*}{$0.02 *$} & 3.61 & 1.99 & \multirow[t]{3}{*}{1.05} & \multirow[t]{3}{*}{0.35} \\
\hline & $\begin{array}{l}\text { Biosciences \& } \\
\text { Medical }\end{array}$ & 3.80 & 1.55 & & & 3.56 & 1.45 & & \\
\hline & $\begin{array}{l}\text { Physical } \\
\text { Sciences \& } \\
\text { Engineering }\end{array}$ & 3.59 & 1.31 & & & 3.80 & 1.43 & & \\
\hline \multirow[t]{3}{*}{ Affective } & Social Sciences & 3.67 & 1.09 & \multirow[t]{3}{*}{14.55} & \multirow[t]{3}{*}{$0.00^{*}$} & 3.49 & 1.33 & \multirow[t]{3}{*}{5.27} & \multirow[t]{3}{*}{$0.01 *$} \\
\hline & $\begin{array}{l}\text { Biosciences \& } \\
\text { Medical }\end{array}$ & 3.39 & 1.02 & & & 3.28 & 1.08 & & \\
\hline & $\begin{array}{l}\text { Physical } \\
\text { Sciences \& } \\
\text { Engineering }\end{array}$ & 3.17 & 0.92 & & & 3.11 & 1.08 & & \\
\hline
\end{tabular}

Note: * Significant at 0.05

The means of the perception level of achievement in teaching and learning domains from Social Science cluster are as follows; Cognitive - 4.48, Psychomotor - 3.99, Affective - 3.67. These are higher compared to those achieved by the students from other clusters. This shows that the three major domains in teaching and learning were adequately applied by all lecturers in their instructions.

There is a significant difference between the level of perception of utilization of teaching and learning domains by lecturers from different clusters in Semester I 2006/2007 as presented in. For Semester II 2006/2007, it is seen that there is no significant different between the levels of perception among lecturers form different clusters especially in the two domains of cognitive and psychomotor. 
Table 8. Distribution of Respondents by the Level of Attainment of Learning Outcomes through Courses by Cluster

\begin{tabular}{|l|l|l|l|l|l|l|}
\hline \multirow{2}{*}{ Cluster } & \multicolumn{3}{l}{ Semester I 2006/2007 } & \multicolumn{3}{l|}{ Semester II 2006/2007 } \\
\cline { 2 - 8 } & 1 & $\mathbf{2}$ & $\mathbf{3}$ & 1 & $\mathbf{2}$ & $\mathbf{3}$ \\
\hline & $\%$ & \multicolumn{5}{l|}{$\%$} \\
\hline Social Science & 6.5 & 25.3 & 68.3 & 7.6 & 18.6 & 73.8 \\
\hline Biosciences \& Medical & 13.2 & 25.0 & 61.9 & 13.9 & 21.6 & 64.6 \\
\hline Physical Sciences \& Engineering & 12.6 & 26.2 & 57.5 & 14.8 & 27.6 & 57.6 \\
\hline Average & 10.8 & 25.5 & 62.6 & 12.1 & 22.6 & 65.3 \\
\hline
\end{tabular}

Note: 1- Low 2-Moderate 3-High

Majority of the lecturers perceived that the students are highly fluent in attaining all the eight elements of learning outcomes as proposed by MoHE for all courses. It constitutes 62.6\% of attainment in Semester I 2006/2007 and 65.3\% for Semester II 2006/2007 of the total samples.

Table 9. Mean Score for the Attainment of Learning Outcomes through Courses

\begin{tabular}{|l|l|l|l|l|}
\hline \multirow{2}{*}{ Learning Outcomes through Courses } & \multicolumn{2}{l|}{ Semester I 2006/2007 } & \multicolumn{2}{l|}{ Semester II 2006/2007 } \\
\cline { 2 - 5 } & Mean Score & SD & Mean Score & SD \\
\hline Life Long Learning and Information Management & 7.17 & 2.03 & 7.45 & 2.19 \\
\hline Communication Skills & 6.83 & 6.83 & 6.79 & 2.41 \\
\hline Critical Thinking and Scientific Approach & 7.06 & 1.89 & 7.20 & 2.18 \\
\hline Managerial and Entrepreneurial Skills & 5.23 & 2.65 & 5.18 & 2.77 \\
\hline Psychomotor / Practical / Technical Skills & 6.66 & 2.49 & 6.59 & 2.72 \\
\hline Knowledge & 8.33 & 1.57 & 8.37 & 1.92 \\
\hline Social skills and Responsibility & 6.90 & 2.27 & 6.74 & 2.60 \\
\hline Professionalism, Values, Attitudes and Ethics & 7.06 & 2.27 & 6.94 & 2.56 \\
\hline
\end{tabular}

Note: $0-3=$ Low, $4-6=$ Moderate, $7-10=$ High

The highest perception level goes to the KNOWLEDGE SKILLS where in both semester it was ranked the highest at 8.33 and 8.37 respectively (Table 9). Except for MANAGERIAL AND ENTREPRENEURIAL SKILL which ranked as 'Low' (i.e. 5.23 and 5.18 respectively) the rest of the learning outcomes were fairly perceived at 'High' levels of achievement. 
Table 10. Analysis of Variance for Learning Outcomes by Cluster

\begin{tabular}{|c|c|c|c|c|c|c|c|c|c|}
\hline \multirow[t]{2}{*}{ Taxonomy } & \multirow[t]{2}{*}{ Cluster } & \multicolumn{4}{|c|}{ Semester I 2006/2007 } & \multicolumn{4}{|c|}{ Semester II 2006/2007 } \\
\hline & & Mean & SD & $\mathbf{F}$ & Sig-F & Mean & SD & $\mathbf{F}$ & Sig-F \\
\hline \multirow{3}{*}{$\begin{array}{lr}\text { Life } & \text { Long } \\
\text { Learning and } \\
\text { Information } \\
\text { Management }\end{array}$} & Social Science & 7.43 & 1.79 & 4.25 & $0.02 *$ & 7.82 & 1.79 & 5.09 & $0.01 *$ \\
\hline & $\begin{array}{l}\text { Biosciences } \quad \& \\
\text { Medical }\end{array}$ & 6.99 & 2.22 & & & 7.20 & 2.49 & & \\
\hline & $\begin{array}{l}\text { Physical Sciences } \\
\text { \& Engineering }\end{array}$ & 6.97 & 2.13 & & & 7.28 & 2.17 & & \\
\hline \multirow{3}{*}{$\begin{array}{l}\text { Communication } \\
\text { Skills }\end{array}$} & Social Science & 7.35 & 1.85 & 17.53 & $0.00^{*}$ & 7.64 & 1.90 & 20.86 & $0.00 *$ \\
\hline & $\begin{array}{l}\text { Biosciences } \quad \& \\
\text { Medical }\end{array}$ & 6.47 & 2.23 & & & 6.45 & 2.52 & & \\
\hline & $\begin{array}{l}\text { Physical Sciences } \\
\text { \& Engineering }\end{array}$ & 6.42 & 1.97 & & & 6.28 & 2.53 & & \\
\hline \multirow{3}{*}{$\begin{array}{l}\text { Critical Thinking } \\
\text { and Scientific } \\
\text { Approach }\end{array}$} & Social Science & 7.12 & 1.77 & 0.36 & 0.70 & 7.18 & 1.93 & 0.48 & 0.62 \\
\hline & $\begin{array}{l}\text { Biosciences } \quad \& \\
\text { Medical }\end{array}$ & 6.97 & 2.08 & & & 7.13 & 2.30 & & \\
\hline & $\begin{array}{l}\text { Physical Sciences } \\
\text { \& Engineering }\end{array}$ & 7.06 & 1.89 & & & 7.34 & 2.27 & & \\
\hline \multirow{3}{*}{$\begin{array}{l}\text { Managerial and } \\
\text { Entrepreneurial } \\
\text { Skills }\end{array}$} & Social Science & 5.64 & 2.55 & 8.94 & $0.00 *$ & 5.83 & 2.55 & 9.86 & $0.00 *$ \\
\hline & $\begin{array}{l}\text { Biosciences } \quad \& \\
\text { Medical }\end{array}$ & 5.19 & 2.76 & & & 4.84 & 2.92 & & \\
\hline & $\begin{array}{l}\text { Physical Sciences } \\
\text { \& Engineering }\end{array}$ & 4.64 & 2.59 & & & 4.75 & 2.71 & & \\
\hline \multirow{3}{*}{$\begin{array}{l}\text { Psychomotor / } \\
\text { Practical / } \\
\text { Technical Skills }\end{array}$} & Social Science & 6.43 & 2.54 & 3.61 & $0.03 *$ & 6.20 & 2.75 & 3.68 & $0.03 *$ \\
\hline & $\begin{array}{l}\text { Biosciences } \quad \& \\
\text { Medical }\end{array}$ & 7.04 & 2.54 & & & 6.85 & 2.65 & & \\
\hline & $\begin{array}{l}\text { Physical Sciences } \\
\text { \& Engineering }\end{array}$ & 6.65 & 2.33 & & & 6.78 & 2.68 & & \\
\hline \multirow[t]{3}{*}{ Knowledge } & Social Science & 8.50 & 1.46 & 3.30 & $0.04 *$ & 8.70 & 1.55 & 9.79 & $0.00 *$ \\
\hline & $\begin{array}{l}\text { Biosciences } \quad \& \\
\text { Medical }\end{array}$ & 8.28 & 1.67 & & & 8.51 & 1.75 & & \\
\hline & $\begin{array}{l}\text { Physical Sciences } \\
\text { \& Engineering }\end{array}$ & 8.14 & 1.60 & & & 7.90 & 2.29 & & \\
\hline \multirow{3}{*}{$\begin{array}{l}\text { Social skills and } \\
\text { Responsibility }\end{array}$} & Social Science & 7.63 & 1.89 & 31.31 & $0.00 *$ & 8.06 & 1.90 & 55.94 & $0.00 *$ \\
\hline & $\begin{array}{l}\text { Biosciences } \quad \& \\
\text { Medical }\end{array}$ & 6.54 & 2.35 & & & 6.46 & 2.60 & & \\
\hline & $\begin{array}{l}\text { Physical Sciences } \\
\text { \& Engineering }\end{array}$ & 6.17 & 2.38 & & & 5.59 & 2.64 & & \\
\hline \multirow{3}{*}{$\begin{array}{l}\text { Professionalism, } \\
\text { Values, Attitudes } \\
\text { and Ethics }\end{array}$} & Social Science & 7.79 & 1.75 & 30.93 & $0.00 *$ & 7.86 & 1.96 & 23.66 & $0.00 *$ \\
\hline & $\begin{array}{l}\text { Biosciences } \quad \& \\
\text { Medical }\end{array}$ & 6.64 & 2.54 & & & 6.55 & 2.74 & & \\
\hline & $\begin{array}{l}\text { Physical Sciences } \\
\text { \& Engineering }\end{array}$ & 6.37 & 2.36 & & & 6.32 & 2.60 & & \\
\hline
\end{tabular}

Note: * Significant at 0.05 level

There is a significant difference in the attainment of different learning outcomes (Life Long Learning and Information Management, Communication Skills, Managerial and Entrepreneurial Skills, Psychomotor / Practical / Technical Skills, Knowledge, Social skills and Responsibility and Professionalism, Values, Attitudes and Ethics) by lecturers from different clusters in Semester I 2006/2007 and Semester II 2006/2007. On the other hand, there is no significant difference in the attainment of learning outcomes in courses related to Critical Thinking and Scientific Approach among different clusters. 


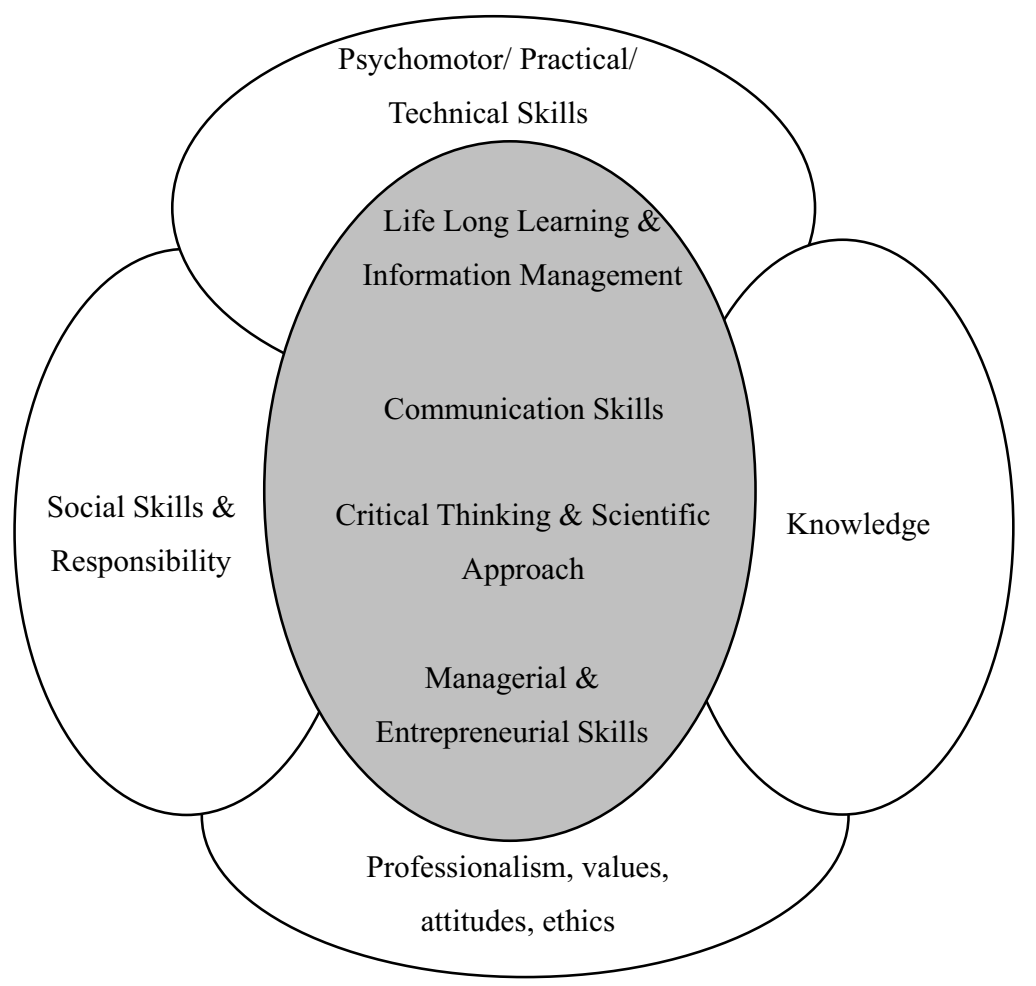

Figure 1. Categories of Learning Outcomes

This figure demonstrates the skills expected of each category of domains. These eight learning outcomes are the most influential factors in providing quality education. Details are provided in the Appendix 1. 